Canadian

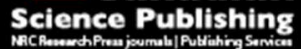

Canadian Journal of Forest Research Revue canadienne de recherche forestière

\title{
Wood ash as a soil amendment in Canadian forests: what are the barriers to utilization?
}

\begin{tabular}{|c|c|}
\hline Journal: & Canadian Journal of Forest Research \\
\hline Manuscript ID & cjfr-2017-0351.R2 \\
\hline Manuscript Type: & Discussion \\
\hline Date Submitted by the Author: & 03-Jan-2018 \\
\hline Complete List of Authors: & $\begin{array}{l}\text { Hannam, Kirsten; University of British Columbia } \\
\text { Venier, Lisa; Canadian Forest Service, } \\
\text { Allen, Darren; Great Lakes Forestry Centre, } \\
\text { Deschamps, Candace; Canadian Forest Service } \\
\text { Hope, Emily; Great Lakes Forestry Centre } \\
\text { Jull, Michael; University of Northern British Columbia College of Science } \\
\text { and Management } \\
\text { Kwiaton, Martin; Ontario Ministry of Natural Resources and Forestry, } \\
\text { Centre for Northern Forest Ecosystem Research } \\
\text { Mckenney, Dan; Great Lakes Forestry Centre } \\
\text { Rutherford, Mike; University of Northern British Columbia College of } \\
\text { Science and Management } \\
\text { Hazlett, Paul; Great Lakes Forestry Centre }\end{array}$ \\
\hline Keyword: & bioenergy, wood ash, forest soil, biomass harvesting, waste management \\
\hline $\begin{array}{r}\text { Is the invited manuscript for } \\
\text { consideration in a Special } \\
\text { Issue? : }\end{array}$ & N/A \\
\hline
\end{tabular}









\section{Abstract}

36 The contribution of forest biomass to Canada's energy production is small but

37 growing. As the forest bioenergy industry in Canada expands, there is growing interest in

38 more sustainably managing the wood ash that is generated as a by-product. Despite being

39 rich in nutrients, wood ash is usually landfilled in Canada. Soil applications of ash in

40 Canadian forests could be used to mimic some of the effects of wildfire; to replace

41 nutrients removed during harvesting: to counteract the negative effects of acid deposition;

42 and to improve tree growth. At present, the provincial/territorial processes for obtaining

43 regulatory approval to use wood ash as a forest soil amendment can be challenging to

44 navigate. Furthermore, the costs for obtaining approval, transporting and soil-applying

45 wood ash can render landfilling a more cost-effective method of ash management. To

46 ensure that wood ash applications in Canadian forests are conducted safely, effectively

47 and efficiently, experience from European countries could provide a useful starting point

48 for developing best practices. The results of Canadian research trials will assist policy

49 makers and forest managers in refining management guidelines that encourage soil

50 applications of wood ash as a forest management tool while protecting the ecology, water

51 quality, biodiversity and productivity of Canadian forests.

52

53 Keywords (up to 6):

54 bioenergy; wood ash; forest soil; biomass harvesting; waste management. 


\section{Introduction}

56 Canada meets its energy needs using a combination of fossil fuels, nuclear power,

57 and renewables. Efforts to mitigate greenhouse gas emissions depend on replacing fossil

58 fuel-based energy with that from renewable sources. The contribution of renewables to

59 Canada's total energy production is increasing rapidly $(11 \%$ in $2013 ; 16 \%$ in $2014 ; 20 \%$

60 in 2015; Nyboer et al. 2014; Nyboer and Melton 2015; Griffin and Nyboer 2016). At

61 present, hydroelectricity accounts for the bulk of Canada's renewable energy capacity

62 (72\%), followed by biomass (15\%) (Griffin and Nyboer 2016). Approximately 65\% of

63 the biomass combusted is used to provide thermal energy, with increasing amounts used

64 to generate electricity and liquid fuels (Griffin and Nyboer 2016). Most of Canada's

65 renewable energy capacity is used to generate electricity, and the contribution of biomass

66 to electricity generation is also trending upward (from $7875 \mathrm{GWh}$ in 2005 to $13107 \mathrm{GWh}$

67 in 2015; National Energy Board of Canada 2016).

68 The primary users of bioenergy in Canada are the timber and pulp and paper

69 industries, which generate heat and power for on-site use by combusting the by-products

70 of the manufacturing process (e.g., off-cuts, hog fuel, black liquor; Bradburn 2014).

71 Increasingly, however, the use of forest biomass for energy is diversifying. Many

72 Canadian provinces and territories have implemented policies that promote investment in

73 forest biomass-based energy production. For example, as required under the

74 Environmental Protection Act, Ontario Power Generation (OPG) has phased out coal-

75 fired electricity production and converted the generating stations at Thunder Bay and

76 Atikokan to wood or torrefied pellet combustion (Bradburn 2014; Ontario Power

77 Generation 2015). In the Northwest Territories (NWT), the 2010 Biomass Energy 
78 Strategy has facilitated the installation of wood pellet boilers for the provision of

79 residential, commercial and institutional heating; with the goal of 'leading by example',

80 twenty-eight pellet boiler systems have been installed in government facilities across the

81 NWT and currently provide $24 \%$ of the government's total heat requirements

82 (Government of the Northwest Territories 2017).

83 The forest industry is already the largest producer of bioenergy in Canada

84 (Bradburn 2014; Roach and Berch 2014; Griffin and Nyboer 2016). Declining demand

85 for traditional forest products (e.g., newsprint, lumber) has encouraged investment in

86 emerging products (e.g., wood pellets) that can be used to generate bioenergy both

87 domestically and abroad (Roach and Berch 2014; Lamers et al. 2016). Wood pellets can

88 be produced from a variety of woody materials that have, until recently, had little

89 economic value. Wood processing residues, tree branches, tops and un-merchantable

90 stems that were traditionally piled at the roadside and burned or left within the stand to

91 decay; trees salvaged after insect outbreaks or wildfire; and dead woody material

92 generated during stand break-up and self-thinning are viewed as possible source material

93 for pellet production (Ontario Ministry of Natural Resources 2008; Dymond et al. 2010;

94 Roach and Berch 2014). There is enormous potential to further expand energy production

95 in Canada using forest biomass (Dymond et al. 2010; Yemshanov et al. 2014; Paré et al.

96 2016).

97 The expansion of forest bioenergy capacity across the country will also increase

98 the rate of wood ash production. Wood ash is often treated as a waste material in Canada,

99 and landfilled, although this situation is changing. In 1995, 84\% of the ash produced in

100 power and recovery boilers at Canadian pulp and paper mills was landfilled; by 2013, 
101 landfilling rates had fallen to 63\% (Elliott and Mahmood 2006; Elliott and Mahmood

102 2015). Nevertheless, wood ash management practices vary considerably among

103 provinces. Approximately half of the ash produced each year in Alberta ( 30 $000 \mathrm{Mg}$; G.

104 Dinwoodie, Land Reclamation Specialist - Alberta Environment and Parks, Land Policy

105 Branch, personal communication, September 2016) and Québec ( 150 000 Mg; Hébert

106 and Breton 2009) is soil-applied; the remainder is usually landfilled. By contrast, almost

107 all of the ash produced each year in British Columbia pulp and paper mills, sawmills and

108 bioenergy plants is landfilled ( 226 $000 \mathrm{Mg}$; Nishio 2016).

109 Depending on its chemical and physical properties, wood ash can have a wide

110 range of beneficial uses, e.g., liming agent and fertilizer on agricultural soils; capping

111 material at landfills; road aggregate; fill material in building construction; cement

112 manufacturing; odour absorbent (Elliott and Mahmood 2006; Knapp and Insam 2011;

113 Swedish Energy Ashes 2014). Numerous studies have also demonstrated that applications

114 of wood ash on forest soils can be used to replace some of the nutrients (e.g., phosphorus

115 (P), calcium $(\mathrm{Ca})$, magnesium $(\mathrm{Mg})$, potassium $(\mathrm{K}))$ removed during forest harvesting; to

116 counteract the acidifying effects of atmospheric deposition on forest soils and surface

117 water bodies; and to improve tree growth (Augusto et al. 2008; Reid and Watmough

118 2014; Huotari et al. 2015). In several European countries, forest soil applications of wood

119 ash are encouraged, particularly on sites from which harvesting residues have been

120 removed for bioenergy production (Skogsstyrelsen 2008; Stupak et al. 2008; Forestry

121 Commission 2009). Thus, disposal of wood ash in Canadian landfills may represent a

122 wasted opportunity to obtain greater economic value from forest biomass and to more 
123 sustainably manage the forest resource by closing a loop in the cycling of nutrients during

124 forestry operations. The objectives of this paper are to:

125

126

127

128

\section{Possible benefits of using wood ash as a forest soil amendment in Canada}

134 demonstrating the utility of wood ash as a soil amendment on forest sites. We provide

135 some selected references to illustrate that soil applications of wood ash can be used to

136 meet a number of complementary forest management objectives.

138 To mimic some of the effects of wildfire on soil properties

139 Increasingly, management practices that 'emulate natural disturbance' (END) are

140 being promoted as a means of accommodating conflicting demands for ecological and

141 economic goods and services from Canadian forests (Perera et al. 2004; Ontario Ministry

142 of Natural Resources 2010; Stockdale et al. 2016). Wildfire is the dominant high-

143 mortality disturbance agent in forest ecosystems across much of Canada (Government of

144 Canada 2015). Although wood ash applications do not impose the same high surface soil

145 temperatures associated with wildfire or cause a rapid oxidation of the forest floor layer 
146 (Nave et al. 2011), they can elevate soil $\mathrm{pH}$ and enhance concentrations of $\mathrm{Ca}, \mathrm{Mg}$ and $\mathrm{K}$

147 (Augusto et al. 2008; Huotari et al. 2015; Reid and Watmough 2014) in a similar manner

148 to wildfire (Certini 2005; Bodí et al. 2014; Maynard et al. 2014). Thus, applications of

149 wood ash may have potential as a management tool for END (Noyce et al. 2016).

150

151 To replace nutrients removed during biomass harvesting

152 In 2013, woody biomass provided $26 \%$ and $31 \%$ of total primary energy needs in

153 Finland and Sweden, respectively (Thiffault et al. 2016). Most of this energy was derived

154 from the combustion of small diameter woody residues generated during stand thinning,

155 timber harvesting and wood processing (Thiffault et al. 2016). Given that a significant

156 quantity of the nutrients (e.g., $\mathrm{Ca}, \mathrm{Mg}, \mathrm{K}$ and $\mathrm{P}$ ) contained in forest biomass can be

157 recovered in the ash fraction remaining after combustion (Ingerslev et al. 2011), the

158 practice of returning wood ash to the forest can be used to replenish ecosystem nutrient

159 pools and preserve forest productivity after intensive biomass removal (Skogsstyrelsen no

160 date; Karltun et al. 2008; Skogsstyrelsen 2008). Indeed, wood ash can improve foliar P, K

161 and Ca concentrations for decades after application (Augusto et al. 2008; Reid and

162 Watmough 2014). To ensure that the nutrients removed during biomass harvesting are

163 replaced during ash application, Finland, Lithuania and Sweden have established

164 minimum $\mathrm{Ca}, \mathrm{K}$ and $\mathrm{P}$ content limits for any wood ash that is used as a forest soil

165 amendment (Stupak et al. 2008).

166

167 To counteract the acidifying effects of atmospheric deposition and forest harvesting 
169 waters and soils, and depletion of soil base cation pools on acid-sensitive sites in central

170 Europe and north-eastern North America (Driscoll et al. 2003; Canadian Council of

171 Ministers of the Environment 2008; European Environmental Agency 2012). This

172 phenomenon has been shown to alter lake ecology and has raised concerns that soils and

173 forests on base-poor sites have been rendered more sensitive to biological acidification

174 caused by nutrient removals associated with timber and biomass removal (Watmough et

175 al. 2003; Jeziorski et al. 2008, McLaughlin, 2014; Löfgren et al. 2017). According to a

176 recent meta-analysis (of predominantly European and North American studies), biomass

177 harvesting can lower the $\mathrm{pH}$ and base saturation of surface soils and reduce

178 concentrations of foliar calcium in the regenerating stand, but only when foliage is

179 removed along with tree stems and branches (Achat et al. 2015). Research has shown that

180 applications of wood ash can be used to increase soil $\mathrm{pH}$ and base saturation, thereby

181 increasing surface water $\mathrm{pH}$ which, in turn, may facilitate the ecological recovery of

182 surface waters (Westling and Zetterberg 2007; Johansson 2014; Huotari et al. 2015).

184 To improve tree growth

185 Applications of wood ash do not consistently improve tree growth. Current

186 evidence suggests that a positive growth response to applications of wood ash is most

187 likely on N-rich sites, including forests that receive high rates of atmospheric $\mathrm{N}$

188 deposition, and stands established on naturally fertile peatland or mineral soils (Jacobson

189 et al. 2014; Huotari et al. 2015). On these sites, ash is believed to stimulate the decay of

190 soil organic matter, releasing $\mathrm{N}$ which can then be taken up by tree roots (Augusto et al. 
191 2008; Karltun et al. 2008; Huotari et al. 2015). Tree growth typically remains unchanged

192 or even decreases when wood ash is applied to mineral soils where forest productivity is

193 limited by the availability of N (Augusto et al. 2008; Karltun et al. 2008; Huotari et al.

194 2015).

195

196 Current barriers in Canada to the use of wood ash as a forest soil amendment

197 The process of obtaining regulatory approval is challenging

198 The use of wood ash as a soil amendment is largely under provincial or territorial

199 jurisdiction and, consequently, it varies significantly across Canada. In addition,

200 oversight of soil applications of wood ash are administered by various government

201 departments, and ash can be classified differently (e.g., solid waste, fertilizer, soil

202 amendment) depending on the mandate of the department under which ash management

203 falls in each jurisdiction. In many provinces and territories, ash is defined as a waste

204 material that should be landfilled. As such, some form of environmental impact

205 assessment is often required to obtain approval to apply it to forest or agricultural soils

206 (Hannam et al. 2016). In other provinces, an approval process has been put in place for

207 soil applications of wood ash, specifically, (Alberta Environment 2002) or for soil

208 applications of industrial by-products, in general, (Government of Ontario 2002;

209 Government of British Columbia 2007; Hébert 2008; New Brunswick Department of

210 Environment and Local Government 2014; Hébert 2015) but the focus is on agricultural

211 systems. Furthermore, the application process is often confusing, onerous and time-

212 consuming (Hannam et al. 2016). 
214 Landfilling is often the most cost-effective method of ash disposal

215 The economic costs of soil-applying wood ash are another important potential

216 barrier to the increased diversion of wood ash from the landfill (van Eijk et al. 2012;

217 Risse 2013). Regulatory costs include both the fees associated with obtaining approval to

218 apply wood ash on forest sites and with creating landfill space and depositing the ash in a

219 landfill. The construction of new landfills for wood ash disposal is typically more costly

220 than application on forest soils (Hope et al. 2017). Given that some jurisdictions are

221 becoming reluctant to grant long-term approval to landfill wood ash, insisting instead on

222 the development of more sustainable ash management strategies, the use of wood ash as a

223 soil amendment may become increasingly cost-effective from a regulatory standpoint.

224 Pre-treatment costs are those associated with processing wood ash to ease its

225 handling and application to the soil. In Canada, water is typically added to suppress dust,

226 facilitate ash removal from the boiler, and extinguish any remaining embers (Sylvis

227 Environmental, 2008; Hébert and Breton 2009) but, in general, wood ash is not processed

228 any further. In some European countries, however, ash pre-treatment (or 'stabilization') is

229 recommended. Ash pre-treatment involves wetting the ash and allowing highly reactive

230 and caustic oxides in the ash to react with carbon dioxide and water, and 'harden' into

231 more chemically stable carbonates (Emilsson 2006; Karltun et al. 2008). This pre-

232 treatment step is believed to prevent scorching of vegetation, prolong the fertilization

233 effect of wood ash and reduce the mobility of heavy metals (Emilsson 2006; Pitman

234 2006; Skogsstyrelsen 2008).

235 Finally, transportation costs include the fees associated with transporting the ash

236 and ash spreading equipment to and from the application site or landfill. In general, the 
237 use of wood ash as a soil amendment is not economically viable when sites are located

238 more than $100 \mathrm{~km}$ from the ash production facility (Hope et al. 2017).

240 Ash quality can be highly variable

241 The chemical and physical properties of wood ash are highly variable (Table 1).

242 Ash properties are strongly affected by the moisture content, physical form and tree

243 species composition of the feedstock, the type of combustion system utilized, and the

244 combustion conditions applied (Elliott and Mahmood 2006; Pitman 2006; James et al.

245 2014). Furthermore, ash properties vary depending on their physical point of origin

246 within biomass boilers. Typically, fly ash is more enriched in trace elements than bottom

247 ash (Narodoslawsky and Obernberger 1996; Swedish University of Agricultural Sciences

248 2008; Nurmesniemi et al. 2011). Ash chemistry data from paired sets of Canadian fly and

249 bottom ash samples demonstrate this trend (Figure 1).

250 There is some concern that soil applications of ash-borne trace elements could

251 lead to contamination of forest soil, water and biota (Aronsson and Ekelund 2004; Pitman

252 2006; Augusto et al. 2008; Huotari et al. 2015). This concern can be addressed, in part,

253 by collecting and managing fly and bottom ash fractions separately and by basing ash

254 dosage rates on the results of their chemical analyses (Government of Ontario 2002;

255 Sylvis Environmental 2008; New Brunswick Department of Environment and Local

256 Government 2014; Hébert 2015). In most provinces and territories, the trace element

257 limits set for compost by the Canadian Council of Ministers of the Environment (CCME)

258 are applied to wood ash that will be used as a soil amendment (Canadian Council of

259 Ministers of the Environment 2005; Hannam et al. 2016). According to these criteria, soil 
260 applications of wood ash can be 'unrestricted', 'restricted' or 'not permitted', depending

261 on ash trace metal concentrations (Figure 2; Table 2). Of the 13 provinces and territories

262 in Canada, four (Alberta, British Columbia, Ontario and Quebec) have developed their

263 own trace element limits, which would apply to wood ash used as a soil amendment;

264 these are often modified versions of the CCME trace element limits (Hannam et al.

265 2016).

266 According to the CCME guidelines, trace element limits for unrestricted wood ash

267 applications in Canada (Table 2, CCME Compost A) are generally lower than limiting

268 values for wood ash in Europe (Table 3). Trace elements limits for wood ash that can be

269 used in restricted applications (CCME Compost B) are generally higher than limiting

270 values for wood ash in Europe (Table 3). This suggests that, under current guidelines,

271 wood ash with higher concentrations of trace elements could legally be applied to

272 Canadian forest soils than to European forest soils, as long as provincial or territorial

273 control measures are followed. That being said, the mean concentrations of chromium,

274 cobalt, copper, lead and nickel in fly and bottom ash sampled from Canadian boilers, and

275 cadmium, molybdenum and zinc in bottom ash sampled from Canadian boilers were less

276 than the CCME Category A limits (Figure 2). Wood ash with these concentrations could

277 also be applied under European regulations. Although mean concentrations of arsenic in

278 fly and bottom ash sampled from Canadian boilers, and cadmium and zinc in fly ash

279 sampled from Canadian boilers were greater than the Category A limits (Figure 2), they

280 were still generally below European limits (Table 3).

281 Studies have shown that wood ash composition can be improved via careful

282 control of feedstock quality and combustion conditions (Narodoslawsky and Obernberger 
283 1996; Elliott and Mahmood 2006; Nurmesniemi et al. 2011). Indeed, some measures

284 have been put in place in a few Canadian provinces to improve the quality of ash used as

285 a soil amendment, but these are typically focussed on preventing organic compound

286 contamination, rather than reducing trace element concentrations. To prevent

287 contamination of soils with dioxins and furans (persistent organic pollutants formed

288 during the combustion of chloride-containing organic materials), for example, British

289 Columbia prohibits soil applications of fly ash produced from wood that has been

290 immersed in marine waters (Government of British Columbia 2007). If wood ash

291 becomes more widely recognized as a valuable commodity, bioenergy producers could be

292 motivated to more carefully manipulate feedstock quality and combustion conditions to

293 improve wood ash chemical characteristics.

295 Lack of knowledge of the effects of wood ash applications specifically on forest sites

296 At present, none of the provincial/territorial policies and regulations that apply to

297 forestry operations in Canada encourage soil applications of wood ash. In order to

298 maintain support from the Canadian public for expanding bioenergy production (and the

299 ash that it generates), guidance is required that directly addresses the use of wood ash as a

300 forest soil amendment. Research trials have been established in British Columbia,

301 Saskatchewan, Manitoba, Ontario, Québec and Prince Edward Island (Table 4). The trials

302 are linked through AshNet (http://cfs.nrcan.gc.ca/projects/140), a nascent national

303 network investigating wood ash applications in Canadian forests, and are designed to

304 examine the implications for tree growth, water quality and biodiversity of applying

305 wood ash to forest soils. Given that most of the trials have been established in the last 10 
306 years, monitoring is ongoing and only initial results ( $<5$ years after ash application) have

307 been published for a limited number of sites (Table 4). To date, however, the overall

308 effects of ash application on forest soils in Canada appear to be similar to those observed

309 in European trials. To illustrate this point, the effects of ash application on soil $\mathrm{pH}$ and

310 tree growth for a few sites are briefly summarised below.

311 The short-term effects of wood ash application on soil $\mathrm{pH}$ in Canadian wood ash

312 trials have mostly been positive but treatment effects vary with ash dosage rate and soil

313 depth. In a young jack pine plantation in northeastern Ontario (Island Lake site; Table 4),

314 for example, forest floor $\mathrm{pH}$ was increased two years after the application of 5.6 $\mathrm{Mg} \mathrm{ha}^{-1}$

315 of wood ash but not after the application of $0.7 \mathrm{Mg} \mathrm{ha}^{-1}, 1.4 \mathrm{Mg} \mathrm{ha}^{-1}$ or $2.8 \mathrm{Mg} \mathrm{ha}^{-1}$ of

316 wood ash (Noyce et al. 2016). In an uneven-aged hardwood forest in central Ontario

317 (Haliburton site; Table 4), forest floor $\mathrm{pH}$ was increased one year after the application of

$3184 \mathrm{Mg} \mathrm{ha}^{-1}$ or $8 \mathrm{Mg} \mathrm{ha}^{-1}$ of fly ash or bottom ashes but not after the application of $1 \mathrm{Mg}$ ha

$319{ }^{1}$ of fly or bottom ashes (Noyce et al. 2016). In a $\sim 53$ year-old boreal stand in

320 northwestern Québec (Senneterre-1 site; Table 4), forest floor pH increased in the first

321 year following application of $2 \mathrm{Mg} \mathrm{ha}^{-1}$ or $8 \mathrm{Mg} \mathrm{ha}^{-1}$ of wood ash, and treatment effects

322 remained constant at years 2 and 5 (Brais et al. 2015). In a white spruce plantation in

323 north-central BC, forest floor $\mathrm{pH}$ had increased five months after the application of $5 \mathrm{Mg}$

$324 \mathrm{ha}^{-1}$ low-carbon gasifier ash or high-carbon boiler ash; treatment effects were strongest

325 following the application of gasifer ash, particularly when applied in combination with

$326100 \mathrm{~kg} \mathrm{ha}^{-1}$ urea (Domes et al. in press). In all of the above studies, wood ash application

327 had no significant effect on the $\mathrm{pH}$ of the surface $(0-10 \mathrm{~cm})$ mineral soil. In a white

328 spruce plantation in northwestern Saskatchewan (Meadow Lake site; Table 4), however, 
329 increased soil $\mathrm{pH}$ was observed at $0-10 \mathrm{~cm}, 10-20 \mathrm{~cm}$ and $20-30 \mathrm{~cm}$ soil depths two years

330 after the application of $5 \mathrm{Mg} \mathrm{ha}^{-1}$ of wood ash (though not after the application of $1 \mathrm{Mg}$

$331 \mathrm{ha}^{-1}$ of wood ash; Staples and Van Rees 2001).

332 The short-term effects of wood ash applications on tree growth in Canadian wood

333 ash trials have mostly been negative. In a nine year-old western red cedar plantation on

334 Vancouver Island, British Columbia (Port McNeill site; Table 4), reduced height growth

335 was observed every year for five years after application of $5 \mathrm{Mg} \mathrm{ha}^{-1}$ of wood ash

336 (McDonald et al. 1994; Prescott and Brown 1998). At the Senneterre-1 site, no change in

337 the growth of jack pine or small diameter $(\mathrm{dbh}<10 \mathrm{~cm})$ black spruce was observed five

338 years after application of $8 \mathrm{Mg} \mathrm{ha}^{-1}$ of wood ash, but the growth of large diameter (dbh >

$33910 \mathrm{~cm}$ ) black spruce was reduced (Brais et al. 2015). At the Meadow Lake site, reduced

340 height and diameter growth was observed two years after application of $5 \mathrm{Mg} \mathrm{ha}^{-1}$ of

341 wood ash (Staples and Van Rees 2001).

342 Continued assessments of these experimental trials will help answer questions

343 concerning the longer-term effects of wood ash applications on soil properties and site

344 productivity in Canadian forest ecosystems. For example, reviews of European trials

345 suggest that increased soil $\mathrm{pH}$ in deeper mineral soils, and enhanced tree growth are more

346 often observed > 10 years after ash additions (Pitman 2006; Reid and Watmough 2014).

347 Linking the Canadian research sites through AshNet will also enable researchers to

348 identify research gaps and ensure that critical environmental indicators are being

349 monitored across a broad range of forest and soil types.

351 Developing guidelines for the use of wood ash as a forest soil amendment in Canada 
While ongoing monitoring of Canadian wood ash trials will provide much needed

353 information on the ecological effects of wood ash applications, it is not practical to wait

354 until all the implications are known before relevant policies can be revised or developed

355 (Puddister et al. 2011). European standards for wood ash applications on forest soils can

356 provide an initial framework for the development of Canadian guidelines.

358 Sites to which ash should not be applied

359 Some provinces/territories discourage the removal of harvesting residues on sites

360 with nutrient-poor soils (Roach and Berch 2014). At the same time, most

361 provinces/territories discourage the use of soil amendments on sites with coarse-textured

362 or shallow soils because of concerns over nutrient leaching and water contamination

363 (Hannam et al. 2016). Such policies contrast with those developed for Finland, Lithuania,

364 Sweden and the United Kingdom (UK), where applications of wood ash are encouraged

365 to prevent nutrient deficiencies following biomass harvesting, particularly on nutrient-

366 poor sites (Karltun et al. 2008; Raulund-Rasmussen et al. 2008; Forestry Commission

367 2009).

368 European guidelines have identified several types of sites to which wood ash

369 should not be applied. In order to prevent $\mathrm{N}$ leaching and contamination of surface water,

370 applications of wood ash are not recommended in the UK on upland forest soils that

371 receive high rates of atmospheric $\mathrm{N}$ deposition (Pitman 2006; Forestry Commission

372 2009) or in Sweden on N-rich clearcuts that are adjacent to watercourses (Skogsstyrelsen

373 2008). In Sweden, ash applications are not recommended on sites with sensitive flora,

374 such as sphagnum moss, because burning of foliage has been observed (Karltun et al. 
375 2008; Skogsstyrelsen 2008). In Denmark, analysis of forest soils is mandatory prior to

376 wood ash applications, and dosage rates are calculated to ensure that the concentrations

377 of trace elements in the soil remain below specified limits (Stupak et al. 2008). Soil

378 testing is also required in Austria if trace element concentrations in the ash are above

379 specified limits (van Eijk et al. 2012). Such restrictions could be particularly important on

380 sites that are naturally enriched in certain trace elements or that have been contaminated

381 by industrial activity (Pitman 2006). In fact, soil analysis of trace elements would already

382 be required in order to obtain approval to apply wood ash in many Canadian jurisdictions

383 (Hannam et al. 2016).

384

385 Optimal dosage rates

386 In Canada, wood ash dosage rates for agricultural applications are typically

387 calculated from the characteristics of the ash and receiving soil (Alberta Environment

388 2002; Government of Ontario 2002; Sylvis Environmental 2008; Hébert 2015). Similar

389 considerations are used when determining ash dosage rates for forest applications in

390 many European countries (Stupak et al. 2008). For example, several countries, including

391 Austria, Denmark, Finland, Germany, Lithuania and Sweden, have set strict limits on the

392 maximum concentrations of trace elements allowed in any ash to be used as a forest soil

393 amendment (Table 3; Stupak et al. 2008; van Eijk et al. 2012). Measured concentrations

394 of trace elements in the ash and (in some countries) receiving soil, together with

395 maximum recommended ash dosage rates, are used to ensure that ash applications do not

396 substantially increase trace element loads within forest ecosystems (Stupak et al. 2008;

397 van Eijk et al. 2012). However, other site factors can also be considered, e.g., the tree 
398 species composition and fertility of the soil (Emilsson 2006; Stupak et al. 2008;

399 Varnagirytė-Kabašinskienè 2012); the acidity of atmospheric deposition (Stupak et al.

400 2008); and/or the quantity of nutrients removed during harvesting (Emilsson 2006;

401 Skogsstyrelsen 2008; Stupak et al. 2008).

402 No maximum dosage rates have been developed specifically for wood ash

403 applications on forest soils in Canada. Instead, maximum dosage rates for wood ash (or

404 soil amendments, in general) in Canada were developed with a focus on agricultural soils

405 and are typically much higher than those recommended for forest soils in Europe (Table

$4065)$.

407

408 Optimal application timing and frequency

409 Applications of wood ash in clearcut management systems could probably be

410 conducted during site preparation, prior to replanting, in order to reduce the number of

411 stand entries and minimize damage to regenerating trees (Lomander et al. 2005; Emilsson

412 2006). During thinning or partial harvesting operations, machinery trails could be used to

413 access the stand for ash spreading without damaging retained trees. Due to concerns

414 about $\mathrm{K}$ and nitrate leaching, several European guidelines suggest that ash only be

415 applied on sites with established vegetation (Emilsson 2006; Skogsstyrelsen 2008; Stupak

416 et al. 2008) and that only very stable ash products be applied on clearcuts (Emilsson

417 2006; Wildbacher 2007; Skogsstyrelsen 2008). Recommendations in some European

418 guidelines for ash applications later in stand development appear to be motivated by the

419 desire to improve forest productivity and/or pre-emptively replace nutrients that will be 
420 removed during future harvests (Pitman 2006; Stupak et al. 2008; Varnagirytè-

421 Kabašinskienè 2012).

422

423 Co-applications of wood ash with $N$-rich amendments

424 Co-applications of ash and $\mathrm{N}$ are recommended in Sweden for vigorously

425 growing stands (Emilsson 2006), and for sites with low levels of $\mathrm{N}$ deposition and high

426 levels of biomass extraction (Skogsstyrelsen 2008). Applications of granules produced

427 from a mixture of wood ash and N-rich pulp and paper mill sludge have also been

428 proposed (Emilsson 2006). To date, the effects on tree growth and foliar nutrition of co-

429 applications of wood ash with urea (Brais et al. 2015) and N-rich fish silage (Prescott and

430 Brown 1998) have been reported for two forest sites in Canada but, in both studies,

431 increased tree growth appeared to be a response to the added $\mathrm{N}$ and not the wood ash.

\section{Conclusions}

434 Forest biomass is a relatively small but growing source of renewable energy in Canada.

435 As the forest bioenergy industry expands, disposal of the ash generated during the 436 combustion process will become a more important issue. At present, much of the wood

437 ash produced in Canada is landfilled. Its use as a soil amendment on forest sites could

438 mimic some of the effects of wildfire on soil processes in logged forests, help replace the

439 nutrients removed during biomass harvesting, counteract the effects of acid deposition on

440 soil and surface water, and prolong the lifespan of landfills. The long-term effects of ash

441 applications on forest productivity require more study. At present, the process for

442 obtaining regulatory approval to apply wood ash on forest soils is seen as a significant 
443 barrier in Canada. As well, the costs of obtaining approval, transporting and applying ash

444 often render landfilling the most cost-effective option for disposal. Recognition of the

445 potential economic value of wood ash could encourage bioenergy producers to more

446 carefully control feedstock composition and combustion conditions in order optimize ash

447 quality. To ensure that wood ash applications on Canadian forest sites are conducted

448 safely, effectively and efficiently, guidelines developed for countries in Europe may be

449 instructive.

450

\section{Acknowledgements}

452 Funding for this work was provided by the Program of Energy Research and

453 Development (PERD) (Project Identification Number 2C03.003 BIO 026). PERD played

454 no role in the preparation or submission of this report. Additional support was provided

455 by Natural Resources Canada's Aboriginal Forestry Initiative, in collaboration with the

456 Pic Mobert First Nation. The authors would like to thank Mike Brienesse, Joe Churcher,

457 Paul Glassford and Jim Rice of the Ontario Ministry of Natural Resources and Forestry

458 for their valuable insight and discussion. The authors also gratefully acknowledge the

459 assistance of members of AshNet who provided wood ash samples for analyses as a

460 contribution to the Ash Chemistry Database. We also thank two anonymous reviewers for

461 their constructive comments on the original manuscript.

\section{References}


Achat, D.L., Deleuze, C., Landman, G., Pousse, N., Ranger, J., and Augusto, L. 2015. Quantifying consequences of removing harvesting residues on forest soils and tree growth - A meta-analysis. For. Ecol. Manage 348: 124-141.

Alberta Environment. 2002. Standards and guidelines for the use of wood ash as a liming material for agricultural soils. Available from:

http://environment.gov.ab.ca/info/library/6680.pdf [accessed 22 July 2016]

Aronsson, K.A. and Ekelund, N.G.A. 2004. Biological effects of wood ash application to forest and aquatic ecosystems. J. Environ. Qual. 33: 1595-1605.

Augusto, L., Bakker, M.R. and Meredieu, C. 2008. Wood ash applications to temperate forest ecosystems - potential benefits and drawbacks. Plant Soil 306: 181-198. doi: 10.1007/s11104-008-9570-z.

Bodí, M.B., Martin, D.A., Balfour, V.N., Santín, C. Doerr, S.H., Pereira, P., Cerdà, A., and Mataix-Solera, J. 2014. Wildland fire ash: Production, composition and eco-hydrogeomorphic effects. Earth-Science Reviews 130: 103-127. doi:

10.1016/j.earscirev.2014.07.005.

Bradburn, K. 2014. CANBIO report on the status of bioenergy in Canada. Available from: http://www.fpac.ca/wp-content/uploads/2014 CanBio Report.pdf [accessed 22 July 2016]. 
Brais, S., Bélanger, N. and Guillemette, T. 2015. Wood ash and N fertilization in the Canadian forest forest: soil properties and response of jack pine and black spruce. For. Ecol. Manage. 348: 1-14. doi: 10.1016/j.foreco.2015.03.021.

Canadian Council of Ministers of the Environment. 2005. Guidelines for Compost Quality. Available from:

http://www.ccme.ca/files/Resources/waste/compost_quality/compostgdlns 1340 e.pdf [accessed 22 July 2016]

Canadian Council of Ministers of the Environment. 2008. A national picture of acid deposition critical loads for forest soils in Canada. PN 1412. Available from: http://www.ccme.ca/files/Resources/air/acid_rain/national_picture acid_deposition_pn14 12.pdf [accessed 22 July 2016]

Certini. G. 2005. Effects of fire on properties of forest soils: a review. Oecologia 143: 110. doi: 10.1007/s00442-004-1788-8.

Domes, K.A., de Zeeuw, T., Massicotte, H.B., Elkin, C., McGill, W.B., Jull, M.J., Chisholm, C.E. and Rutherford, P.M. In press. Short-term changes in spruce foliar nutrients and soil properties in response to wood ash application in the sub-boreal climate zone of British Columbia. Can. J. Soil Sci. 
Driscoll, C.T., Driscoll, K.M., Mitchell, M.J., and Raynal, D.J. 2003. Effects of acidic deposition on forest and aquatic ecosystems in New York State. Environ. Poll. 123: 327336. doi: 10.1016/S0269-7491(03)00019-8.

Dymond, C.C., Titus, B.D., Stinson, G. and Kurz, W.A. 2010. Future quantities and spatial distribution of harvesting residue and dead wood from natural disturbances in Canada. For. Ecol. Manage. 260: 181-192. doi: 10.1016/j.foreco.2010.04.015.

Elliott, A. and Mahmood, T. 2006. Beneficial uses of pulp and paper power boiler ash residues. TAPPI Journal 5: 9-16.

Elliott, A. and Mahmood, T. 2015. Generation and management of solid residues by Canadian pulp and paper mills in 2013. Confidential report prepared for FPInnovations.

Emilsson, E. 2006. From extraction of forest fuels to ash recycling: international handbook. Available from:

http://ec.europa.eu/environment/life/project/Projects/index.cfm?fuseaction=home.showFi

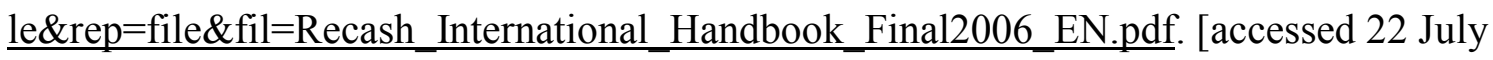
2016]

European Environmental Agency. 2012. Exceedance of critical loads of acidity [online] Available from http://www.eea.europa.eu/data-and-maps/figures/exceedance-of-crititalloads-of-acidity [accessed 22 July 2016]. 
Forestry Commission. 2009. Guidance on site selection for brash removal. Available from:

http://www.forestry.gov.uk/pdf/Brash residue protocol.pdf/\$file/Brash residue protocol .pdf [accessed 22 July 2016]

Gorgolewski, A., Caspersen, J., Hazlett, P., Jones, T., Tran, H., and Basiliko, N. 2016. Responses of Eastern Red-backed Salamander (Plethodon cinereus) abundance 1 year after application of wood ash in a northern hardwood forest. Can. J. For. Res. 46: 402409. doi: 10.1139/cjfr-2015-0230.

Government of British Columbia. 2007. Code of practice for soil amendments under the Environmental Act and the Public Health Act. Available from: http://www.British Columbialaws.ca/Recon/document/ID/freeside/210_2007. [accessed 22 July 2016]

Government of Canada. 2015. National Forest and Forest Management Statistics. Available from: http://nfdp.ccfm.org/index e.php [accessed 22 July 2016]

Government of Ontario 2002. Nutrient Management Act. O. Reg. 267/03: GENERAL. Available from: https://www.ontario.ca/laws/regulation/030267. [accessed 22 July 2016]

Government of the Northwest Territories. 2017. 2030 Energy Strategy - A Path to More Affordable, Secure and Sustainable Energy in the Northwest Territories. August 2017 
Draft for Public Comment. Available from:

https://www.inf.gov.nt.ca/sites/inf/files/resources/gnwt_inf_7047_energy_strategy_p7_0. pdf. [accessed December 2017].

Griffin, B., and Nyboer, J. 2016. Renewable Energy in Canada 2015. Canadian Industrial Energy End-use Data and Analysis Centre. Simon Fraser University, Burnaby, B.C. Available from:

http://www2.cieedac.sfu.ca/media/publications/Renewable_Energy_Report_2016_Final.pdf (accessed 29 August 2016).

Hannam, K.D., Deschamps, C., Kwiaton, M., Venier, L. and Hazlett, P.W. 2016. Regulations and guidelines for the use of wood ash as a soil amendment in Canadian forests. Information Report GLC-X-18.

Hébert, M. 2008. Guidelines for the Beneficial Use of Fertilising Residuals - Edition 2008. Available from: http://www.mddelcc.gouv.qc.ca/matieres/mat res$\underline{\text { en/fertilisantes/critere/guide-mrf.pdf [accessed } 22 \text { July 2016] }}$

Hébert, M. 2015. Guide sur le recyclage des matières résiduelles fertilisantes: Critères de référence et norms réglementaires - Edition 2015. Available from: http://www.mddelcc.gouv.qc.ca/matieres/mat_res/fertilisantes/critere/guide-mrf.pdf [accessed 22 July 2016] 
Hébert, M and Breton, B. 2009. Agricultural wood ash recycling in Québec and in northern climate: current situation, impact and agri-environmental practices. Available from: http://www.weao.org/assets/docs/residualsBiosolids/2009-5th-canadian-residualsand-biosolids-presentation.pdf [accessed 22 July 2016]

Hope, E.S., McKenney, D.W., Allen, D.J. and Pedlar, J.H. 2017. A cost analysis of bioenergy-generated ash disposal options in Canada. Canadian Journal of Forest Research 47: 1222-1231.

Huotari, N., Tillman-Sutela, E., Moilanen, M. and Laiho, R. 2015. Recycling of ash - For the good of the environment? For. Ecol. Manage. 348: 226-240. doi: 10.1016/j.foreco.2015.03.008.

Ingerslev, M., Skov, S., Sevel, L., and Pedersen, L.B. 2011. Element budgets of forest biomass combustion and ash fertilisation - A Danish case-study. Biomass Bioenergy 35: 2697-2704.

Jacobson, S., Lundstrom, H., Nordlund, S., Sikstrom, U. and Pettersson, F. 2014. Is tree growth in boreal coniferous stands on mineral soils affected by the addition of wood ash? Scand. J. For. Res. 29: 675-685.

James, A.K., Helle, S.S., Thring, R.W., Sarohia, G.S., and Rutherford, P.M. 2014. Characterization of inorganic elements in woody biomass bottom ash from a fixed-bed 
combustion system, a downdraft gasifier and a wood pellet burner by fractionation. Energy Environ. Res. 4: 85-94. doi: 10.5539/eer.v4nlp85.

Jeziorski, A., Yan, N.D., Paterson, A.M., DeSellas, A.M., Turner, M.A., Jeffries, D.S., Keller, B. Weeber, R.C., McNicol, D.K., Palmer, M.E., McIver, K., Arseneau, K., Ginn, B.K., Cumming, B. F., Smol, J.P. 2008. The widespread threat of calcium decline in fresh waters. Science 322: 1374-1377. doi: 10.1126/science.1164949.

Johansson, M. 2014. Wood-ash application on forest soil - a meta-analysis of the effects on surface water acid-base chemistry. M.Sc. thesis. Faculty of Forest Sciences. Swedish Agricultural University, Umeå, Sweden.

Karltun, E., Saarsalmi, A., Ingerslev, M., Mandre, M., Andersson, S., Gaitnieks, T., Ozolinčius, R., Varnagiryte-Kabasinskiene, I. 2008. Wood ash recycling - possibilities and risks. In D. Röser, A. Asikainen, K. Raulund-Rasmussen and I. Stupak (eds.) Sustainable use of forest biomass for energy: a synthesis with focus on the Baltic and Nordic Region. pp. 79-108. Springer, Dordrecht, The Netherlands.

Knapp, B.A. and Insam, H. 2011. Recycling of biomass ashes: current technologies and future research needs. In Insam, H. and B.A. Knapp (eds) Recycling of Biomass Ashes. pp. 1-16. Springer, Dordrecht, The Netherlands. 
Lamers, P., Mai-Moulin, T., and Junginger, M. 2016. Challenges and opportunities for international trade in forest biomass. In E. Thiffault, G. Berndes, M. Junginger, J.N. Saddler and C.T. Smith (eds.). Mobilisation of forest bioenergy in the boreal and temperate biomes: challenges, opportunities and case studies. pp. 127-164. Academic Press, London, UK.

Lomander, A., Wallstedt, A. and Kalén, C. 2005. Recirculating wood ash - theory, practise and recommendations. Available from:

http://www.skogsstyrelsen.se/Global/myndigheten/Projekt/RecAsh/Utbildningsmaterial\% 20Education $\% 20$ Material/3.\%20Utbildningsmaterial $\% 20$ på\%20engelska $\% 20$ Internationa 1\%20Education $\% 20$ Package/Askåterföring, $\% 20$ teori, $\% 20$ praktik $\% 20$ och $\% 20$ rekommend ationer\%20(engelska).pdf [accessed 22 July 2016]

Löfgren, S., Ågran, A., Gustafsson, J.P., Olsson. B.A., and Zetterberg, T. 2017. Impact of whole-tree harvest on soil and stream water acidity in southern Sweden based on HDMINTEQ simulations and pH-sensitivity. For. Ecol. Manage. 383: 49-60. http://dx.doi.org/10.1016/j.foreco.2016.07.018.

Mahendrappa, M.K., Pitt, C.M., Kingston, D.G.O., and Morehouse, T. 2006.

Environmental impacts of harvesting white spruce on Prince Edward Island. Biomass Bioenergy 30: 363-369. doi: 10.1016/j.biombioe.2005.07.016. 
Maynard, D.G., Paré, D., Thiffault, E., Lafleur, B., Hogg, K.E., and Kishchuk, B. 2014. How do natural disturbances and human activities affect soils and tree nutrition and growth in the Canadian boreal forest? Environ. Rev 22: 161-178. doi: 10.1139/er-20130057.

McDonald, M.A., Hawkins, B.J., Prescott, C.E., and Kimmins, J.P. 1994. Growth and foliar nutrition of western red cedar fertilized with sewage sludge, pulp sludge, fish silage and wood ash on northern Vancouver Island. Can. J. For Res. 24: 297-301.

McLaughlin, J.W. 2014. Forest soil calcium dynamics and water quality: implications for forest management planning. Soil Sci. Soc. Am. J. 78: 1003-1020. doi: 10.2136/sssaj2013.11.0474.

Narodoslawsky, M. and Obernberger, I. 1996. From waste to raw material - the route from biomass to wood ash for cadmium and other heavy metals. J. Hazard. Mater. 50: $157-168$.

National Energy Board of Canada. 2016. Canada's renewable power landscape: Energy market analysis 2016. Available from: https://www.nebone.gc.ca/nrg/sttstc/lctrct/rprt/2016cndrnwblpwr/2016cndrnwblpwr-eng.pdf (accessed 28 October 2016). 
Nave, L.E., Vance, E.D., Swanston, C.W., and Curtis, P.S. 2011. Fire effects on temperate forest soil C and N storage. Ecol. Appl. 21: 1189-1201. doi: 10.1890/100660.1.

New Brunswick Department of Environment and Local Government. 2014. Guidelines for the Beneficial Use of Industrial By-Products as Soil Amendments. Available from: http://www2.gnb.ca/content/dam/gnb/Departments/env/pdf/LandWasteTerreDechets/GuidelinesForSoilAmendments.pdf [accessed 22 July 2016]

Nishio, G. 2016. Forest biomass ash production in British Columbia. Confidential report prepared for FPInnovations.

Noyce, G.L., Fulthorpe, R., Gorgolewski, A., Hazlett, P., Tran, H., and Basiliko, N. 2016. Soil microbial responses to wood ash addition and forest fire in managed Ontario forests. Appl. Soil Ecol. 107: 368-380. doi: 10.1016/j.apsoil.2016.07.006.

Nurmesniemi, H., Makela, M., Poykio, R., and Dahl, O. 2011. Comparison of the fertilizer properties of ash fractions from medium-sized (32MW) and small-sized (6 MW) municipal district heating plant. Int. J. Eng. Appl. Sci. 7: 87-91.

Nyboer, J., and Melton, N. 2015. Renewable Energy in Canada 2014. Canadian Industrial Energy End-use Data and Analysis Centre. Simon Fraser University, Burnaby, B.C. Available from: 
http://www2.cieedac.sfu.ca/media/publications/Renewable_Energy_Report_Final-1.pdf [Accessed 4 October 2016].

Nyboer, J., Melton, N., and Goldberg, S. 2014. Renewable Energy in Canada 2013.

Canadian Industrial Energy End-use Data and Analysis Centre. Simon Fraser University, Burnaby, B.C. Available from:

http://www2.cieedac.sfu.ca/media/publications/Renewables_Report_Final.pdf [Accessed 4 October 2016].

Obernberger, I., and Supancic, K. 2009. Possibilities of ash utilisation from biomass combustion plants. In ETA-Renewable Energies. Proceedings of the $17^{\text {th }}$ European Biomass Conference \& Exhibition, Hamburg, Germany, June/July 2009. pp. 1-12. ETA Renewable Energies, Italy.

Ontario Ministry of Natural Resources. 2008. Forest biofibre - allocation and use. For. Manag. Br., Toronto, ON. For. Manag. Direct. FOR 0302 01. Available from: https://dr6j45jk9xcmk.cloudfront.net/documents/3099/stdprod-099834.pdf (accessed 16 October 2016).

Ontario Ministry of Natural Resources. 2010. Forest management guide for conserving biodiversity at the stand and site scales. Queen's Printer for Ontario, Toronto, ON. Available from: https://dr6j45jk9xcmk.cloudfront.net/documents/4816/stand-amp-siteguide.pdf (accessed 13 October 2016). 
Ontario Power Generation. 2015. From coal to biomass: Generating a sustainable future. Available from:

http://www.opg.com/about/environment/documents/opgbiomassconversion.pdf. (accessed 22 March 2016).

Paré, D., Thiffault, E., Cyr, G., and Guindon, L. 2016. Quantifying forest biomass mobilisation potential in the boreal and temperate biomes. In E. Thiffault, G. Berndes, M. Junginger, J.N. Saddler and C.T. Smith (eds.). Mobilisation of forest bioenergy in the boreal and temperate biomes: challenges, opportunities and case studies. pp. 36-50. Academic Press, London, UK.

Perera, A.H. Buse, L.J., and Weber M.G. (Eds.), 2004. Emulating Natural Forest Landscape Disturbances: Concepts and Applications. Columbia University Press, NY, pp. 315 .

Pitman, R.A. 2006. Wood ash use in forestry - a review of the environmental impacts. Forestry 79: 563-588. doi: 10.1093/forestry/cp1041.

Prescott, C.E. and Brown, S.M. 1998. Five-year growth response of western redcedar, western hemlock and amabilis fir to chemical and organic fertilizers. Can. J. For Res. 28: $1328-1334$. 
Puddister, D., Dominy, S.W.J., Baker, J.A., Morris, D.A. Maure, J., Rice, J.A., Jones, T.A., Majumdar, I., Hazlett, P.W., Titus, B.D., Fleming, R.L., and Wetzel, S. 2011. Opportunities and challenges for Ontario’s bioeconomy. For. Chron. 87: 468-477.

Raulund-Rasmussen, K., Stupak, I., Clarke, N., Callesen, I., Helmisaari, H-S., Karltun, I., and Varnagiryte-Kabasinskiene, I. 2008. Effects of very intensive forest biomass harvesting on short and long term site productivity. In D. Röser, A. Asikainen, K. Raulund-Rasmussen and I. Stupak (eds.) Sustainable use of forest biomass for energy: a synthesis with focus on the Baltic and Nordic Region. pp. 155-196. Springer, Dordrecht, The Netherlands.

Reid, C. and Watmough, S.A. 2014. Evaluating the effects of liming and wood-ash treatment on forest ecosystems through systematic meta-analysis. Can. J. For. Res. 44: 867-885. doi: 10.1139/cjfr-2013-0488.

Risse, M. 2013. Best management practices for wood ash as agricultural soil amendment. The University of Georgia Cooperative Extension. Bulletin 1142. Available from: http://extension.uga.edu/publications/detail.cfm?number=B1142 [accessed 12 October 2016]

Roach, J., and Berch, S.M. 2014. A compilation of forest biomass harvesting and related policy in Canada. Prov. B.C., Victoria, B.C. Tech. Rep. 081. Available from: https://www.for.gov.bc.ca/hfd/pubs/docs/tr/TR081.pdf (accessed 16 August 2016). 
Skogsstyrelsen . no date. Regular recycling of wood ash to prevent waste production: RecAsh - A Life-environment demonstration project. Available from: http://ec.europa.eu/environment/life/project/Projects/index.cfm?fuseaction=home.showFi le\&rep=file\&fil=LIFE03 ENV S 000598 LAYMAN.pdf [accessed 22 July 2016]

Skogsstyrelsen. 2008. Recommendations for extraction of harvesting residues and ash recycling. Available from:

http://www.skogsstyrelsen.se/Global/PUBLIKATIONER/InEnglish/guidelines.pdf [accessed 22 July 2016]

Staples, T.E. and Van Rees, K.C.J. 2001. Wood/sludge ash effects on white spruce seedling growth. Can. J. For. Res. 81: 85-92.

Stockdale, C., Flannigan, M., and Macdonald, E. 2016. Is the END (emulation of natural disturbance) a new beginning? A critical analysis of the use of fire regimes as the basis of forest ecosystem management with examples from the Canadian western Cordillera. Environ. Rev. doi: 10.1139/er-2016-0002

Stupak, I., Asikainen, A., Röser, D., and Pasanen, K. 2008. Review of recommendations for forest energy harvesting and wood ash recycling. In D. Röser, A. Asikainen, K. Raulund-Rasmussen and I. Stupak (eds.) Sustainable use of forest biomass for energy: a 
synthesis with focus on the Baltic and Nordic Region. pp. 155-196. Springer, Dordrecht, The Netherlands.

Swedish Energy Ashes. 2014. Environmentally correct handling of energy ash. Available from: http://www.energiaskor.se/pdf-dokument/Eng-broschyr\%20NY.pdf [accessed 22 July 2016]

Swedish University of Agricultural Sciences. 2008. Wood ash database - wood for energy. Available from: http://woodash.slu.se/eng/stats.cfm (accessed 29 August 2016).

Sylvis Environmental. 2008. Land Application Guidelines for the Organic Matter Recycling Regulation and the Soil Amendment Code of Practice: Best Management Practices. Available from: www2.gov.British Columbia.ca/assets/gov/environment/waste-management/recycling/landappguidelines.pdf [accessed 22 July 2016]

Thiffault, E., Asikainen, A., and Devlin, G. 2016. Comparisons of forest biomass supply chains from the boreal and temperate biomes. In E. Thiffault, G. Berndes, M. Junginger, J.N. Saddler and C.T. Smith (eds.). Mobilisation of forest bioenergy in the boreal and temperate biomes: challenges, opportunities and case studies. pp. 11-35. Academic Press, London, UK. 
van Eijk, R.J., Obernberger, I., and Supancic, K. 2012. Options for increased utilization of ash from biomass combustion and co-firing. KEMA Nederland B.V. Available from: http://www.ieabcc.nl/publications/Ash_Utilization_KEMA.pdf (accessed 15 August 2016)

Varnagirytė-Kabašinskienè, I. 2012. Toward the rational use of forest biomass:

Lithuanian case study. J. For. Sci 58: 465-471.

Watmough, S.A., Aherne, J. and Dillon, P.J. 2003. Potential impact of forest harvesting on lake chemistry in south-central Ontario at current levels of acid deposition. Can. J. Fish. Aquat. Sci. 60: 1095-1103. doi: 10.1139/f03-093.

Westling, O., and Zetterberg, T. 2007. Recovery of acidified streams in forests treated by total catchment liming. Water Air Soil Pollut: Focus. 7: 347-356. doi: 10.1007/s11267006-9107-5.

Wildbacher, N. 2007. BYE/03/G31 Project 'Biomass energy for heating and hot water supply in Belarus - fact sheet ash utilisation'. Available from: http://energoeffekt.gov.by/bioenergy/htdocs/books_media_campaign/Ash_utilisation.pdf (accessed 24 August 2016). 
Yemshanov, D., McKenney, D.W., Fraleigh, S., McConkey, B., Huffman, T., and Smith, S. 2014. Cost estimates of post harvest forest biomass for Canada. Biomass Bioenergy 69: 80-94. doi: 10.1016/j.biombioe.2014.07.002. 


\section{Tables:}

Table 1. Chemical properties of fly and bottom ashes generated in bioenergy plants across Canada. Data represent the mean, range and number of samples of fly ash and bottom ash produced from a range of feedstocks, boilers and provinces across Canada. (Source: AshNet - Ash Chemistry Database http://cfs.nrcan.gc.ca/projects/140).

\begin{tabular}{lcc}
\hline & Fly ash & Bottom ash \\
\hline $\mathrm{pH}$ in $\mathrm{H}_{2} \mathrm{O}$ & $11.3(8.6-13.8) 8$ & $10.9(7.5-12.9) 14$ \\
Total $\mathrm{C}(\%)$ & $18.1(2.7-43) 8$ & $20.4(0.5-51.8) 14$ \\
Total Inorganic $\mathrm{C}(\%)$ & $2.6(0.2-7.2) 3$ & $1.7(0.02-3.3) 6$ \\
Total $\mathrm{N}(\%)$ & $0.2(0.04-0.4) 9$ & $0.09(<0.01-0.3) 14$ \\
Total P $\left(\mathrm{g} \mathrm{kg}^{-1}\right)$ & $6.3(3.2-10.6) 9$ & $4.9(0.1-11.9) 16$ \\
Total $\mathrm{Ca}\left(\mathrm{g} \mathrm{kg}^{-1}\right)$ & $153.5(92.1-247.9) 9$ & $103.7(3.9-211.0) 16$ \\
Total $\mathrm{Mg}\left(\mathrm{g} \mathrm{kg}^{-1}\right)$ & $14.6(6.4-29.4) 9$ & $11.8(0.6-33.1) 16$ \\
Total $\mathrm{K}\left(\mathrm{g} \mathrm{kg}^{-1}\right)$ & $33.1(13.5-90.8) 9$ & $24.1(0.8-50.8) 16$ \\
Total S $\left(\mathrm{g} \mathrm{kg}^{-1}\right)$ & $11.0(<0.1-47.4) 9$ & $3.8(<0.1-25.9) 13$ \\
\hline
\end{tabular}


Table 2. Maximum trace element limits $\left(\mathrm{mg} \mathrm{kg}^{-1}\right)$ applied to wood ash in many Canadian provinces/territories; these limits were originally developed for compost (Source: Canadian Council of Ministers of the Environment 2005).

\begin{tabular}{lcc}
\hline & Category A Compost & Category B Compost \\
\hline Arsenic & 13 & 75 \\
Cadmium & 3 & 20 \\
Chromium & 210 & 1060 \\
Cobalt & 34 & 150 \\
Copper & 400 & 757 \\
Lead & 150 & 500 \\
Mercury & 0.8 & 5 \\
Molybdenum & 5 & 20 \\
Nickel & 62 & 180 \\
Selenium & 2 & 14 \\
Zinc & 700 & 1850 \\
\hline
\end{tabular}

Note: Category A Compost: wood ash with 'trace element' concentrations that fall below the limits set for category A compost is considered 'unrestricted' and can be used as a soil amendment in any application; Category B Compost: wood ash with 'trace element' concentrations that fall above the limits for category A compost but below the limits for category B compost has 'restricted' use and 'may require additional control when deemed necessary by a province or territory'. Wood ash with 'trace element' concentrations above the limits for Category B Compost 'must be used or disposed of appropriately'. 
Table 3. Limiting values $\left(\mathrm{mg} \mathrm{kg}^{-1}\right)$ for trace elements in biomass ash for application on forest lands in European countries (modified from Stupak et al. 2008 and van Eijk et al. 2012).

\begin{tabular}{lcccccc}
\hline & Austria & Denmark & Finland & Germany & Lithuania & Sweden \\
\hline Arsenic & $20 / 20$ & & 40 & 40 & 30 & 30 \\
Cadmium & $5 / 8$ & 20 & 25 & 1.5 & 30 & 30 \\
Chromium & $150 / 250$ & 100 & 300 & & 100 & 100 \\
Copper & $200 / 250$ & & 700 & & 400 & 400 \\
Lead & $100 / 200$ & 250 & 150 & 150 & 300 & 300 \\
Mercury & & 0.8 & 1 & 1 & 3 & 3 \\
Nickel & $150 / 200$ & 60 & 150 & 80 & 70 & 70 \\
Zinc & $1200 / 1500$ & & 4500 & & 700 & 7000 \\
\hline
\end{tabular}

Note: Austria: Class A/Class B: ashes which meet the limiting values of Class A may be applied without a chemical analysis of the soil, ashes with heavy metal contents between the limiting values of Class A and Class B may only be applied after a chemical analysis of the soil shows that the application of ashes is harmless in terms of heavy metal input. 
Table 4. Canadian wood ash field trials.

\begin{tabular}{|c|c|c|c|c|c|c|c|}
\hline Site & Prov. & $\begin{array}{c}\text { Year } \\
\text { established }\end{array}$ & Soil type & $\begin{array}{l}\text { Stand age when } \\
\text { trial established }\end{array}$ & Tree species & Ash applied (dry wt) & References \\
\hline $\begin{array}{l}\text { Aleza Lake } \\
\text { North \& South }\end{array}$ & $\mathrm{BC}$ & 2015 & $\begin{array}{c}\text { Luvisols, } \\
\text { Luvic Gleysols }\end{array}$ & $\begin{array}{l}18 \text { years (North) } \\
24 \text { years (South) }\end{array}$ & $\begin{array}{c}\text { Picea engelmannii } \mathrm{x} \\
\text { Picea glauca }\end{array}$ & $\begin{array}{c}5 \mathrm{Mg} \mathrm{ha}^{-1} \text { untreated bottom } \\
\text { ash }\end{array}$ & $\begin{array}{c}\text { Domes et al. in } \\
\text { press }\end{array}$ \\
\hline Charlottetown ${ }^{*}$ & PEI & 1990 & unknown & Newly planted & $\begin{array}{c}\text { Picea glauca \& Pinus } \\
\text { strobus }\end{array}$ & $\begin{array}{c}0.5 \mathrm{Mg} \mathrm{ha}^{-1} \text { (ash type } \\
\text { unknown) }\end{array}$ & $\begin{array}{c}\text { Mahendrappa et al. } \\
2006\end{array}$ \\
\hline Haliburton & $\mathrm{ON}$ & 2013 & $\begin{array}{l}\text { Dystric } \\
\text { Brunisols }\end{array}$ & Uneven aged & $\begin{array}{c}\text { Acer saccharum, } \\
\text { Fagus grandifolia \& } \\
\text { Betula alleghaniensis } \\
\text { and others }\end{array}$ & $\begin{array}{c}1,4 \text { or } 8 \mathrm{Mg} \mathrm{ha}^{-1} \text { untreated } \\
\text { fly } \& \text { bottom ashes }\end{array}$ & $\begin{array}{l}\text { Noyce et al. 2016; } \\
\text { Gorgolewski et al. } \\
\qquad 2016\end{array}$ \\
\hline Island Lake & $\mathrm{ON}$ & 2011 & $\begin{array}{l}\text { Dystric } \\
\text { Brunisols }\end{array}$ & Newly planted & Pinus banksiana & $\begin{array}{l}0.7,1.4,2.8 \text { or } 5.6 \mathrm{Mg} \mathrm{ha}^{-1} \\
\text { untreated bottom ash }\end{array}$ & Noyce et al. 2016 \\
\hline Meadow Lake & SK & 1995 & Grey Luvisols & Newly planted & Picea glauca & $\begin{array}{c}1 \text { or } 5 \mathrm{Mg} \mathrm{ha}^{-1} \text { hardened } \\
\text { bottom ash }\end{array}$ & $\begin{array}{c}\text { Staples \& Van Rees } \\
2001\end{array}$ \\
\hline Pineland & MB & 2015 & Luvisols & Newly planted & Pinus banksiana & $\begin{array}{c}1.5 \mathrm{Mg} \mathrm{ha}^{-1} \text { mixed fly } \& \\
\text { bottom ash }\end{array}$ & \\
\hline Port McNeill $^{*}$ & $\mathrm{BC}$ & 1990 & $\begin{array}{l}\text { Ferro-Humic } \\
\text { Podzols }\end{array}$ & 9 years & Thuja plicata & $\begin{array}{c}5 \mathrm{Mg} \mathrm{ha}^{-1} \text { (ash type } \\
\text { unknown) }\end{array}$ & $\begin{array}{l}\text { McDonald et al. } \\
\text { 1994; Prescott \& } \\
\text { Brown } 1998\end{array}$ \\
\hline Senneterre - $1^{\dagger}$ & QC & 2005 & $\begin{array}{l}\text { Eluvated } \\
\text { Brunisols }\end{array}$ & 53 years & $\begin{array}{l}\text { Picea mariana \& } \\
\text { Pinus banksiana }\end{array}$ & $\begin{array}{l}1,2,4 \text { or } 8 \mathrm{Mg} \mathrm{ha}^{-1} \\
\text { untreated fly ash }\end{array}$ & Brais et al. 2015 \\
\hline Senneterre -2 & QC & 2006 & $\begin{array}{l}\text { Eluvated } \\
\text { Brunisols }\end{array}$ & Newly planted & $\begin{array}{c}\text { Picea glauca, Pinus } \\
\text { banksiana \& Larix } \\
\text { marschlinsii }\end{array}$ & $\begin{array}{c}2.5 \text { or } 5 \mathrm{Mg} \mathrm{ha}^{-1} \text { untreated } \\
\text { fly ash }\end{array}$ & \\
\hline Senneterre - 3 & QC & 2007 & $\begin{array}{l}\text { Eluvated } \\
\text { Brunisols }\end{array}$ & Newly planted & $\begin{array}{l}\text { Picea mariana \& } \\
\text { Pinus banksiana }\end{array}$ & $\begin{array}{c}7.5 \text { or } 15 \mathrm{Mg} \mathrm{ha}^{-1} \text { untreated } \\
\text { fly ash }\end{array}$ & \\
\hline $25^{\text {th }}$ Sideroad & ON & 2012 & Eutric Brunisols & Newly planted & $\begin{array}{c}\text { Picea glauca \& Picea } \\
\text { mariana }\end{array}$ & $\begin{array}{c}1 \text { or } 10 \mathrm{Mg} \mathrm{ha}^{-1} \text { untreated } \\
\text { fly ash }\end{array}$ & \\
\hline $\begin{array}{l}\text { E. Townships - } \\
\text { poplar }\end{array}$ & QC & 2015 & $\begin{array}{l}\text { Humo-Ferric to } \\
\text { Ferro-Humic } \\
\text { Podzols }\end{array}$ & 3 to 6 years & hybrid Populus & $\begin{array}{c}15 \mathrm{Mg} \mathrm{ha}^{-1} \text { untreated } \\
\text { bottom ash }\end{array}$ & \\
\hline $\begin{array}{l}\text { E. Townships - } \\
\text { maple }\end{array}$ & QC & 2015 & $\begin{array}{l}\text { Humo-Ferric to } \\
\text { Ferro-Humic } \\
\text { Podzols }\end{array}$ & Uneven aged & Acer saccharum & $\begin{array}{c}20 \mathrm{Mg} \mathrm{ha}^{-1} \text { untreated } \\
\text { bottom ash }\end{array}$ & \\
\hline
\end{tabular}


*No longer maintained

${ }^{\dagger}$ Recently harvested

${ }^{\ddagger}$ All values are expressed on a dry weight basis except for the E. Townships sites, which are expressed on a fresh weight basis 
Table 5. Maximum wood ash dosage rates in Europe and Canada

\begin{tabular}{|c|c|c|c|}
\hline \multicolumn{2}{|r|}{ Canada } & \multicolumn{2}{|r|}{ Europe } \\
\hline Alberta & $\begin{array}{l}45 \mathrm{Mg} \mathrm{ha}^{-1} \text { lifetime } \\
\text { agricultural soils } \\
\text { (Alberta Environment 2002) }\end{array}$ & Austria & $\begin{array}{l}2 \mathrm{Mg} \mathrm{ha}^{-1} 20 \text { years }^{-1}(\mathrm{~V} . \\
\text { Bruckman, Austrian } \\
\text { Academy of Sciences, } \\
\text { personal communication, } \\
\text { December 2017). }\end{array}$ \\
\hline CCME & $\begin{array}{l}200 \mathrm{Mg} \mathrm{ha}^{-1} 45 \text { years }^{-1} \\
\text { (Canadian Council of } \\
\text { Ministers of the Environment } \\
\text { 2005). }\end{array}$ & Denmark & $\begin{array}{l}3 \mathrm{Mg} \mathrm{ha}^{-1} 10 \text { years }^{-1} ; 3 \\
\text { applications } 75 \text { years }^{-1}(\mathrm{M} . \\
\text { Ingerslev, University of } \\
\text { Copenhagen, personal } \\
\text { communication, December } \\
\text { 2017). }\end{array}$ \\
\hline Québec & $\begin{array}{l}88 \mathrm{Mg} \mathrm{ha}^{-1} 20 \text { years }^{-1} \\
\text { (Hébert 2015). }\end{array}$ & Lithuania & $\begin{array}{l}\text { 3-7 } \mathrm{Mg} \mathrm{ha}^{-1} \text { rotation }^{-1} \text {, } \\
\text { depending on site type } \\
\text { (Varnagiryte-Kabašinskienè } \\
\text { 2012). }\end{array}$ \\
\hline & & ved & $\begin{array}{l}6 \mathrm{Mg} \mathrm{ha}^{-1} \text { rotation }^{-1}(\mathrm{~S} . \\
\text { Anderson, Swedish Forest } \\
\text { Agency, personal } \\
\text { communication, January } \\
2018) \text {. }\end{array}$ \\
\hline
\end{tabular}




\section{Figure captions:}

\section{Figure 1.}

Differences in the concentrations of ten trace elements, calculated using pairs of fly and bottom ashes generated in seven Canadian biomass boilers. Each symbol represents a pair of fly and bottom ash samples. Values that fall above the zero line indicate trace elements that were more concentrated in fly ash; values that fall below the zero line indicate trace elements that were more concentrated in bottom ash. Few mercury data were available so they are not presented. (Source: AshNet - Ash Chemistry Database

http://cfs.nrcan.gc.ca/projects/140).

\section{Figure 2.}

Average trace element concentrations in fly and bottom ashes generated from a range of feedstocks, boilers and provinces across Canada. Values are means $(+/-$ standard deviation) of 7 to 9 samples of fly ash and 12 to 16 samples of bottom ash. Few mercury data were available so they are not presented. Dashes represent the trace element limits applied to wood ash in many Canadian provinces/territories (Source: AshNet - Ash Chemistry Database http://cfs.nrcan.gc.ca/projects/140; Canadian Council of Ministers of the Environment, 2005). 
Figure 1.

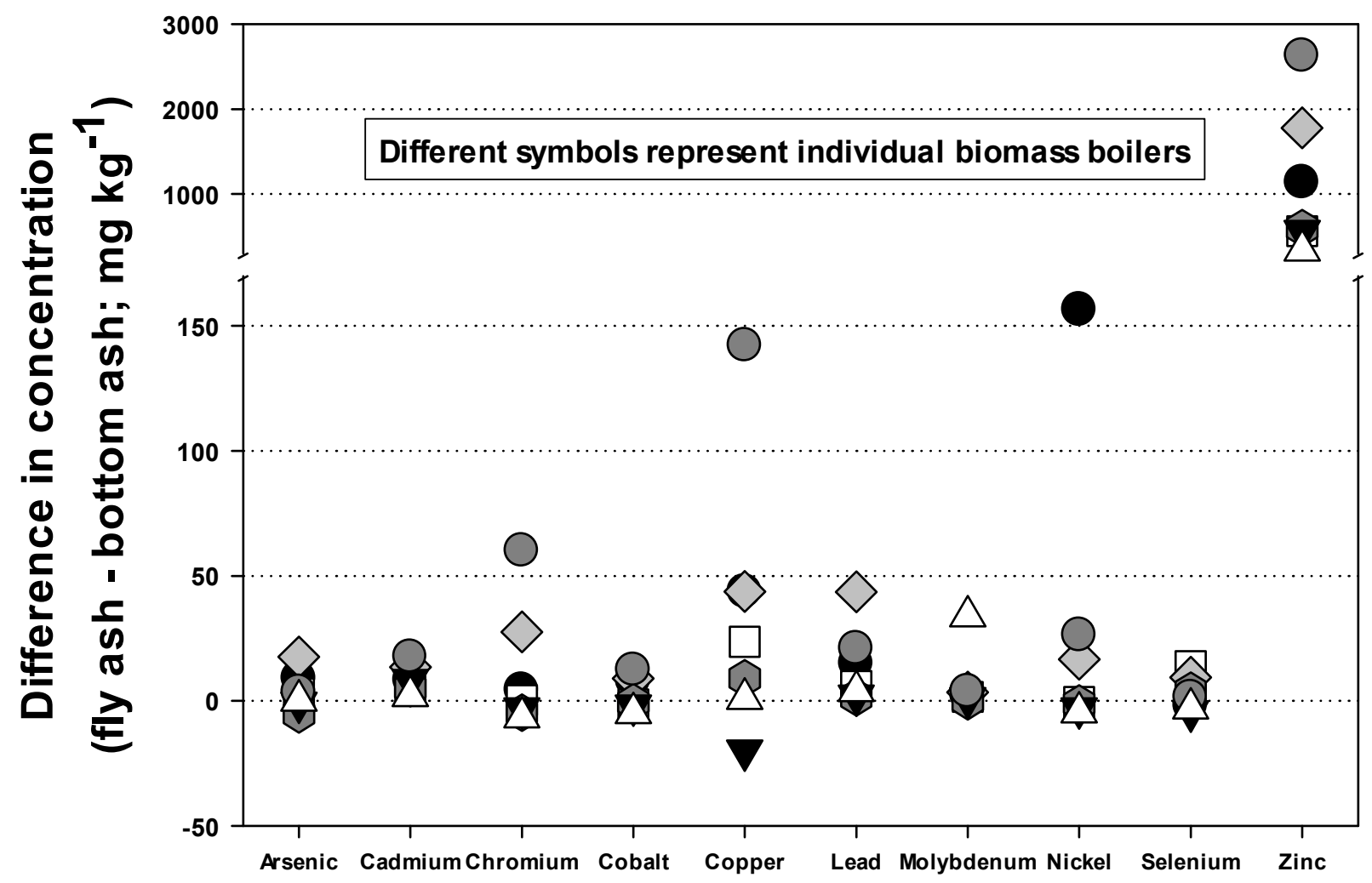


Figure 2a.

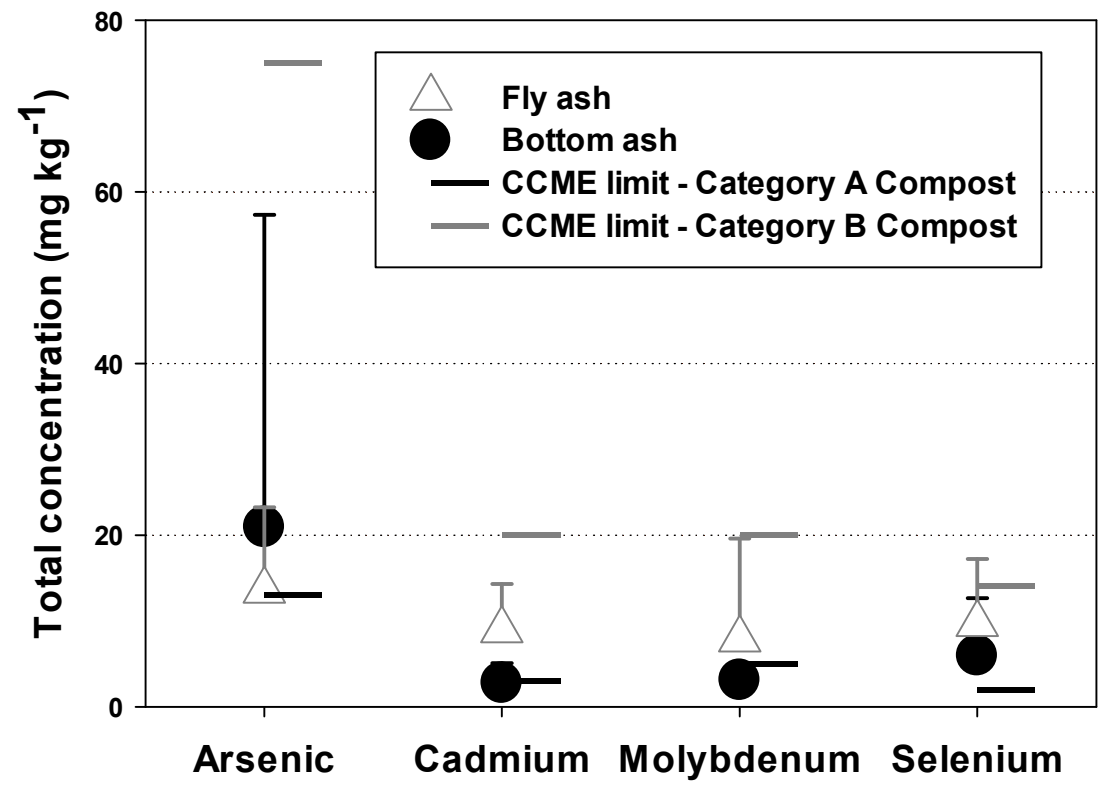

Figure $2 b$.

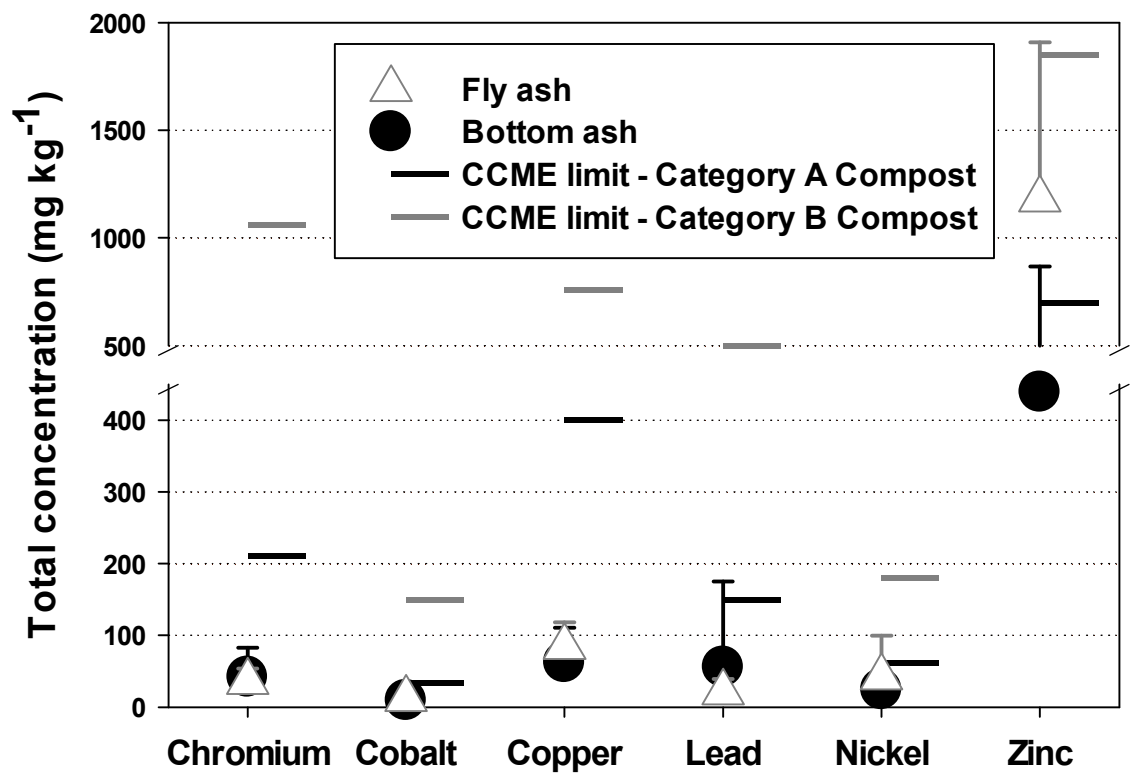

